\title{
A lipid A-associated protein of Porphyromonas gingivalis, derived from the haemagglutinating domain of the RI protease gene family, is a potent stimulator of interleukin 6 synthesis
}

\author{
Lindsay Sharp, ${ }^{1}$ Stephen Poole, ${ }^{3}$ Krisanavane Reddi, ${ }^{2}$ Julie Fletcher, ${ }^{2}$ \\ Sean Nair, ${ }^{1}$ Michael Wilson, ${ }^{2}$ Michael Curtis, ${ }^{4}$ Brian Henderson ${ }^{1}$ \\ and Peter Tabona'
}

1,2 Cellular Microbiology Research Group ${ }^{1}$ and Microbiology Department ${ }^{2}$, Eastman Dental Institute, University College London, 256 Gray's Inn Road, London WC1X 8LD UK

3 Division of Endocrinology, National Institute for Biological Standards and Control, Blanche Lane, South Mimms, Potters Bar EN6 3QG, UK

4 Department of Oral Microbiology, Medical Research Council Molecular Pathogenesis Group, The Royal London School of Medicine and Dentistry, London E1 2AA, UK
Author for correspondence: Brian Henderson. Tel: +44171915 1190. Fax: +441719151190. e-mail : b.henderson@eastman.ucl.ac.uk

There is evidence that the lipid A-associated proteins (LAPs) of enteric bacteria can induce the synthesis of interleukin 1 (IL-1) and therefore may be important virulence factors. Porphyromonas gingivalis is now recognized as a major pathogen in the chronic inflammatory periodontal diseases and it has previously been reported that a crude LAP fraction from this organism could induce IL-1 and interleukin 6 (IL-6) synthesis. In the present study the chemical and biological properties of the LAPs of this bacterium have been further characterized. Analysis by SDS-PAGE has shown that the LAPs comprise nine proteins of molecular masses 81, 68, 48, 47, 28, 25, 20, 17 and $16 \mathrm{kDa}$. These LAPs, at concentrations as low as $100 \mathrm{ng} \mathrm{ml}^{-1}$, were shown to stimulate human gingival fibroblasts, human peripheral blood mononuclear cells and whole human blood to produce the pro-inflammatory cytokine IL-6. The cytokineinducing activity of the LAPs was reduced after heat-inactivation and trypsinization, suggesting that the activity was not due to contaminating LPS. To establish which proteins in this mixture were the active cytokine inducers, the LAPs were separated by electrophoresis on polyacrylamide gels. The majority of the activity was associated with the 17 kDa LAP. N-terminal sequence analysis demonstrated that this protein was homologous to an internal region of a conserved adhesin domain contained within a family of P. gingivalis extracellular proteins including the RI protease, Lys-gingipain, porphypain and haemagglutinin $A$. In addition to a role in adherence, the adhesin domain(s) of these proteins may also have cytokine-inducing properties. Furthermore, it has also been shown that the previously observed degradation of cytokines by P. gingivalis may be attributable to the catalytic domain of the RI protease. Thus, different domains within the same molecule appear to have opposing actions on pro-inflammatory cytokine levels and the balance between these two activities may influence the cytokine status of the periodontium in patients with the common chronic inflammatory conditions known as the periodontal diseases.

Keywords: Porphyromonas gingivalis RI protease, lipopolysaccharide, lipid A-associated protein, interleukin $1 \beta$, interleukin 6 


\section{INTRODUCTION}

The Gram-negative anaerobic bacterium Porphyromonas gingivalis is implicated as an important pathogen in the periodontal diseases (Kurimatsu et al., 1995). Much attention has focused on the endotoxin and LPS of this organism and these components are believed to be major virulence factors of this bacterium. While acute exposure to LPS can produce extensive pathology, it is known that LPS is rapidly inactivated (Emancipator et al., 1996) and repeated exposure produces selective tolerance (Ziegler-Heitbrock et al., 1995). It has also been suggested that $P$. gingivalis LPS (P-LPS) has a weak ability to activate inflammation (Reife et al., 1995). Therefore it is unclear what role LPS plays in chronic inflammation. LPS requires CD14 to produce its full agonist response and a recent report has established that the LPS from $P$. gingivalis has a low affinity for CD14 (Cunningham et al., 1996), again suggesting that this bacterial component may be of limited pathological potential.

It is now established that endotoxin consists of LPS and proteins associated with the LPS in the outer membrane (Bjornson et al., 1988). These proteins, variously known as lipid A-associated proteins (LAPs) (Morrison \& Jacobs, 1976), endotoxin-associated proteins (Phillips $e t$ al., 1989) and endotoxin proteins (Sultzer, 1968), were first recognized when it was discovered that the B cell mitogenic activity of Escherichia coli endotoxin in the LPS non-responder $\mathrm{C} 3 \mathrm{H} / \mathrm{HeJ}$ mouse depended on the protein content of the endotoxin (Sultzer, 1969; Sultzer \& Goodman, 1976). The LAPs are isolated from the endotoxin by hot-phenol extraction to give an operationally defined population of proteins. The LAPs extracted from a number of enteric bacteria have been shown to have potent immunomodulatory properties (Goodman \& Sultzer, 1979b; Sultzer et al., 1985). Furthermore, the enteric LAPs have been noted for their extreme stability to both heat and proteinases (Bjornson et al., 1988; Goodman \& Sultzer, 1979a, b), which accounts for their ability to resist denaturation when extracted in phenol at $68^{\circ} \mathrm{C}$. This stability, linked to the rapid removal and inactivation of LPS by serum proteins (e.g. high-density lipoproteins) (Wurfel et al., 1994, 1995), suggests that the LAPs may play an important role in the biological actions of endotoxin.

In earlier studies we had shown that a preparation of LAPs from $P$. gingivalis was able to stimulate human gingival fibroblasts (HGFs) and the myelomonocytic cell line (Mono-Mac-6) to produce interleukins 1 and 6 (IL1 and IL-6) (Reddi et al., 1995b). In this study we have characterized the LAPs and have identified the components in this population of proteins responsible for cytokine induction.

\section{METHODS}

Extraction of endotoxin. P. gingivalis W50 was grown on Wilkins Chalgren agar (Oxoid) supplemented with $5 \%(\mathrm{v} / \mathrm{v})$ horse blood under anaerobic conditions for $72 \mathrm{~h}$ at $37^{\circ} \mathrm{C}$. The bacterial cultures were Gram-stained to check for contamination with Gram-positive organisms, harvested from the plates by gentle scraping in sterile saline and sedimented by centrifugation at $30000 \mathrm{~g}$ for $30 \mathrm{~min}$ at $4{ }^{\circ} \mathrm{C}$. We had previously demonstrated that $P$. gingivalis contained a large amount of bioactive material on its outer surface (Wilson $e t$ al., 1993). To remove this bioactive extracellular material, the bacteria were resuspended in saline, stirred for $1 \mathrm{~h}$ at $4{ }^{\circ} \mathrm{C}$ and harvested by centrifugation. This process was then repeated. Endotoxin was then extracted from the surface-washed $P$. gingivalis using the method of Morrison \& Leive (1975). Briefly, bacteria were suspended in sterile saline and mixed with an equal volume of water-saturated butanol for $10 \mathrm{~min}$ at $4^{\circ} \mathrm{C}$. The phases were separated by centrifugation at $35000 \mathrm{~g}$ for $20 \mathrm{~min}$ and the aqueous phase was removed. The butanol phase was washed a further two times with approximately half the volume of saline. The aqueous phases were combined and centrifuged to remove any insoluble residues before dialysis for $48 \mathrm{~h}$ with six changes of distilled water at $4{ }^{\circ} \mathrm{C}$. The endotoxin was lyophilized and then washed twice by resuspending in water, followed by ultracentrifugation at $100000 \mathrm{~g}$ for $1 \mathrm{~h}$. The resulting endotoxin pellet was recovered and lyophilized.

Preparation of LAPs. The LAPs were prepared by hot-phenol extraction as described previously (Westphal \& Jann, 1965; Wober \& Alaupovic, 1971). Briefly, the endotoxin was suspended in distilled water and mixed with an equal volume of phenol (Sigma; $90 \%, \mathrm{w} / \mathrm{v}$ ) for $10 \mathrm{~min}$ at $68^{\circ} \mathrm{C}$. The phenol phases were separated by centrifugation at $35000 \mathrm{~g}$ and the aqueous phase was removed. The phenol phase was washed twice more with distilled water, before being dialysed against distilled water for $96 \mathrm{~h}$. The LAPs were then lyophilized and stored at $-70^{\circ} \mathrm{C}$ until required.

Extraction of P-LPS. The aqueous phases from the phenol/ water extraction were pooled and dialysed against distilled water for $96 \mathrm{~h}$, then lyophilized. Protein and nucleic acids were removed by DNase/RNase and proteinase $K$ treatment. The LPS was washed by resuspension in pyrogen-free water and collection by ultracentrifugation at $100000 \mathrm{~g}$ for $1 \mathrm{~h}$ at $4{ }^{\circ} \mathrm{C}$. The wash was repeated before the LPS was lyophilized. P-LPS prepared by the cold $\mathrm{MgCl}_{2}$ method (Darveau \& Hancock, 1983) was also used.

Analysis of LAPs. The protein content of the LAPs was estimated using the detergent-compatible Protein Assay kit (Bio-Rad). The LPS contamination in the LAP preparations was determined by the Limulus amoebocyte lysate (LAL) assay used as described in the European Pharmacopoeia (1997). P-LPS was also assessed in the LAL assay. To remove any contaminating LPS, the LAP preparations were applied to a polymyxin B affinity column (Detoxigel column; Pierce). The LAL assay was used to assess the removal of LPS by this treatment.

The heterogeneity of the LAPs was analysed by SDS-PAGE using the method of Laemmli (1970); 12\% gels were used and the proteins were visualized with colloidal Coomassie blue stain (Sigma).

Heat and trypsin treatment of LAPs. LAPs $\left(10 \mu \mathrm{g} \mathrm{ml}^{-1}\right)$ were digested with trypsin-coated beads $\left(2.5 \mathrm{U} \mathrm{ml}^{-1}\right)$ (Sigma), in $50 \mathrm{mM}$ Tris $/ \mathrm{HCl}, \mathrm{pH} 7 \cdot 6$, at $37^{\circ} \mathrm{C}$ for $2 \mathrm{~h}$. LAPs, at the same concentration, were heat-treated for $45 \mathrm{~min}$ at $85^{\circ} \mathrm{C}$. Materials treated in these ways were tested for activation of IL-6 synthesis by cultured cells. 
Stimulation of IL-6 synthesis by HGFs, human peripheral blood mononuclear cells (PBMCs) and human whole blood. HGFs, prepared from explants of gingivae obtained during routine oral surgery, were used between passages 6 and 12, as described previously (Reddi et al., 1995b). The cells were dispensed into 24-well culture plates at 30000 cells per well and incubated overnight in DMEM containing $2 \%(\mathrm{v} / \mathrm{v})$ foetal calf serum, at $37^{\circ} \mathrm{C}$ in $5 \% \mathrm{CO}_{2} /$ air to allow adherence. The cells were then exposed to various concentrations of the LAPs, P-LPS or E. coli LPS overnight. As a control, cells were incubated with media alone.

Heparinized whole blood, collected from healthy individuals, was diluted five times with RPMI-1640 media; $0.5 \mathrm{ml}$ of this blood mixture was dispensed into the individual wells of 24well culture plates. LAPs or LPS were then added at a range of concentrations to each of the wells and the plates were incubated at $37^{\circ} \mathrm{C}$ in $5 \% \quad \mathrm{CO}_{2}$ for $18 \mathrm{~h}$. The culture supernatants were collected by transferring the contents of each well to sterile microfuge tubes and centrifuging at room temperature for $10 \mathrm{~min}$ at $9000 \mathrm{~g}$. The resultant supernatants were removed and diluted five times in ELISA wash buffer prior to assay of IL-6.

Human PBMCs enriched for monocytes were prepared from buffy coats of mixed human blood (obtained from the South London Blood Transfusion Service, St George's Hospital, London) by Ficol-Hypaque centrifugation and differential adherence. These PBMCs were dispensed into 24-well plates at a density of $2 \times 10^{6}$ cells per well in RPMI-1640 containing $2 \%(\mathrm{v} / \mathrm{v})$ foetal calf serum and were incubated for $24 \mathrm{~h}$ with either various concentrations of the LAPs or LPS. The medium was then collected into microfuge tubes and centrifuged at $10000 \mathrm{~g}$ to remove any cells and then assayed for IL-6.

IL-6 assay. IL-6 immunoassay was performed as described by Taktak et al. (1991). Briefly, microtitre plates were coated with immunoaffinity-purified, polyclonal goat antibodies to human IL-6 at $1 \mu \mathrm{g} \mathrm{ml}^{-1}$ in PBS (140 mM NaCl, $2.7 \mathrm{mM} \mathrm{KCl}$, $1.5 \mathrm{mM} \mathrm{KH}_{2} \mathrm{PO}_{4}, 8.1 \mathrm{mM} \mathrm{Na} \mathrm{HPO}_{4}, \mathrm{pH} 7 \cdot 2$ ) overnight at $4{ }^{\circ} \mathrm{C}$. The unbound antibody was removed from the plates before washing three times with $0.01 \mathrm{M}$ phosphate $/ 0.05 \%$ (w/v) $\mathrm{NaCl}$ containing $0 \cdot 1 \%(\mathrm{v} / \mathrm{v})$ Tween 20 (wash buffer). One hundred microlitres of culture supernatant sample was added to the wells. The standard for IL- 6 was the International Standard for IL-6 preparation 89/548, used over a concentration range from 4 to $9000 \mathrm{pg} \mathrm{m}^{-1}$ in threefold dilutions. The plates were incubated for $2 \mathrm{~h}$ at room temperature before washing three times in wash buffer. Biotinylated, affinitypurified, polyclonal goat anti-IL-6 antibodies were diluted to a concentration of $1 \mu \mathrm{g} \mathrm{ml}^{-1}$ and $100 \mu \mathrm{l}$ was added to each well before incubation at room temperature for $1 \mathrm{~h}$. The plates were washed three times before a 1/5000 dilution of avidinhorseradish peroxidase (Dako) was added to each well and incubated for $15 \mathrm{~min}$ at room temperature. Following three more washes, $100 \mu \mathrm{l} \mathrm{0.2} \mathrm{mg}$ o-phenylenediamine (Sigma) $\mathrm{ml}^{-\mathbf{I}}$ in $0.1 \mathrm{M}$ citric acid/phosphate buffer, $\mathrm{pH} 5.0$, with $0.4 \mu \mathrm{l} 30 \%$ $\mathrm{H}_{2} \mathrm{O}_{2}$ (Sigma) $\mathrm{ml}^{-1}$ was added to each of the wells, and incubated in the dark until the colour started to develop. The reaction was stopped using $150 \mu \mathrm{l} 1 \mathrm{M} \mathrm{H}_{2} \mathrm{SO}_{4}$ (Sigma) and the $A_{492}$ values were measured on a Titertek Multiskan spectrophotometer (Flow Laboratories).

Electrophoretic separation of LAPs. The LAPs were separated by a modification of the conventional SDS-PAGE technique. Approximately $200 \mu \mathrm{g} P$. gingivalis LAPs was dissolved in non-reducing buffer $(0.0625 \mathrm{M}$ Tris $/ \mathrm{HCl}, 10 \%$ glycerol, $0.025 \%$ bromophenol blue) containing $1 \%$ SDS and, rather than boiling, was incubated at room temperature for $1 \mathrm{~h}$.
Proteins were then separated using conventional SDS-PAGE. This modification separated proteins in a similar manner to the conventional SDS-PAGE with denatured proteins. To identify the regions in the gels containing proteins, unstained gels were compared with Coomassie-blue-stained gels and the regions containing distinct protein bands were then cut from the gel and placed into sterile PBS and homogenized. The samples were mixed overnight at $4{ }^{\circ} \mathrm{C}$ to allow the protein to diffuse from the gel. The gel was then removed from the samples by centrifugation down a $0.1 \mathrm{~mm}$ spin column (Whatman) and the samples were dialysed to remove the SDS and then tested for their capacity to stimulate PBMCs to secrete IL-6.

Sequence analysis. LAPs were separated by conventional SDS-PAGE as previously described. The separated proteins were then blotted onto ProBlott membranes (Applied Biosystems) according to the method of Matsudaira (1987). The $\mathrm{N}$-terminal sequences of the LAPs were determined by Edman degradation, using a model $477 \mathrm{~A}$ pulsed liquid protein sequencer (Applied Biosystems). The sequence data obtained were compared with protein and nucleotide databases using the National Centre for Biotechnology Information BLAST network service.

Assessment of IL-1 $\beta$ degradation by purified RI protease. Purified P. gingivalis RI protease (Curtis et al., 1996) was diluted to a concentration of $4 \mathrm{U} \mathrm{m}^{-1}$ in assay buffer $(0.1 \mathrm{M}$ Tris/ $\mathrm{HCl}, \mathrm{pH} 8 \cdot 0,10 \mathrm{mM} \mathrm{Ca}{ }^{2+}, 10 \mathrm{mM}$ cysteine. $\mathrm{HCl}$ ). One unit of RI protease catalyses the formation of $1 \mu \mathrm{mol} p$ nitroaniline $\min ^{-1}$, using the substrate benzoyl-DL-arginine $p$ nitroanilide at $30^{\circ} \mathrm{C}$. Human recombinant IL- $1 \beta$ (a gift from Dr A. Shaw, Glaxo, Geneva) was added to $100 \mu$ l of the enzyme suspension to give a final concentration of $2.5 \mu \mathrm{g} \mathrm{m}^{-1}$ and incubated anaerobically at $37^{\circ} \mathrm{C}$. Samples of $15 \mu \mathrm{l}$ were removed from the tube after incubation times of $15 \mathrm{~min}$, $30 \mathrm{~min}, 1 \mathrm{~h}, 2 \mathrm{~h}$ and $4 \mathrm{~h}$. Human recombinant IL- $1 \beta$ was also incubated for $4 \mathrm{~h}$ with RI protease which had been heatinactivated by boiling for $30 \mathrm{~min}$ in assay buffer. The protease activity was immediately stopped at each sample time by adding an equal volume of $20 \%(\mathrm{v} / \mathrm{v})$ formic acid protein denaturant. The samples were dried on a Speedivac (Savant) and stored at $-70^{\circ} \mathrm{C}$ until they were analysed. To ensure complete inactivation of the RI protease prior to electrophoresis, each of the samples was resuspended in $15 \mu$ l of the protease inhibitor leupeptin $\left.(1 \mathrm{mg} \mathrm{ml})^{-1}\right)$ and incubated at room temperature for $1 \mathrm{~h}$ before heating at $100^{\circ} \mathrm{C}$ for $3 \mathrm{~min}$. Samples were analysed by Western blotting. The reaction mixtures were separated on $18 \%$ SDS-PAGE gels before transferring to Immobilon-P PVDF membranes (Millipore) by the method of Towbin et al. (1979). After incubating for $1 \mathrm{~h}$ in blocking buffer, the membrane was incubated with a $1: 1000$ dilution of sheep anti-human-IL- $1 \beta$ polyclonal antibodies. The bands were detected using a 1:1000 dilution of peroxidaseconjugated rabbit anti-sheep antibodies (Dako) detected by incubation with Sigma Fast 3,3'-diaminobenzidine.

Bioassay to show the loss of activity of IL-1 $\beta$ following digestion with RI protease. Induction of IL-6 release from human monocytes was used to assay the biological activity of IL- $1 \beta$ following digestion with the RI protease. Human monocytes were prepared and plated out as described earlier. The digested IL-1 $\beta$ time-course samples, diluted 1:1250 in DMEM, were added to the wells and incubated overnight at $37^{\circ} \mathrm{C}$ in $5 \% \mathrm{CO}_{2} /$ air. The cell media were then collected and assayed for IL- 6 by ELISA. IL- $1 \beta$ which had not been incubated with RI protease was added to the cells to act as a control. 


\section{RESULTS}

\section{Analysis of $\boldsymbol{P}$. gingivalis LAPs}

The yield of LAPs from $P$. gingivalis was of the order of $0.1 \%$ (weight of LAPs/dry weight of bacteria). Using the detergent-compatible Protein Assay the mean protein content of the isolated LAP preparations was $11 \%$ $(\mathrm{w} / \mathrm{w})$. Previous studies have shown that the remainder of the material is lipid (Reddi et al., 1995b). The preparation of LAPs had an endotoxin activity of 30 $\mathrm{IU} \mu \mathrm{g}^{-1}$ in the LAL assay, which was reduced to $<0.01$ $\mathrm{IU} \mu \mathrm{g}^{-1}$ after passage down a Detoxigel column. Colloidal Coomassie blue staining of the SDS-PAGE gel (Fig. 1) revealed nine protein bands corresponding to approximate molecular masses of $81,68,48,47,28,25$, 20,17 and $16 \mathrm{kDa}$. The P-LPS had an activity in the LAL assay of $3 \times 10^{6} \mathrm{IU} \mathrm{mg} \mathrm{m}^{-1}$. Silver staining of the SDSPAGE gel of P-LPS showed a typical ladder pattern.

\section{IL-6-stimulating activity of LAPs}

The addition of the LAPs to cultured HGFs, monocytes or whole blood caused the dose-dependent production of IL-6 with a maximum effect at $5 \mu \mathrm{g} \mathrm{ml}^{-1}$ with HGFs and PBMCs. In some experiments the LAPs demonstrated significant IL-6-stimulating activity at concentrations as low as $100 \mathrm{ng} \mathrm{ml}^{-1}$ (Fig. 2). Exposure of the LAPs to heat or trypsin caused a significant decrease in the IL-6-inducing activity when added to human monocytes at $1 \mu \mathrm{g} \mathrm{ml}^{-1}\left(1945 \pm 120\right.$ and $1922 \pm 533 \mathrm{pg} \mathrm{ml}^{-1}$, respectively, compared to $3982 \pm 598 \mathrm{pg} \mathrm{ml}^{-1}$ in un-

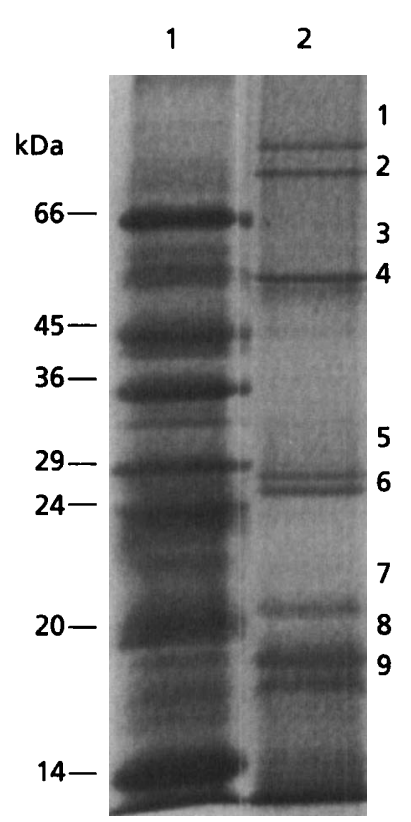

Fig. 1. SDS-PAGE analysis of $P$. gingivalis LAPs stained with Coomassie blue. Lane 1 shows the molecular mass markers and lane 2 shows $P$. gingivalis LAP preparation $\left(10 \mu \mathrm{g} \mathrm{ml}^{-1}\right)$ boiled for $5 \mathrm{~min}$ in reducing buffer. The molecular masses of the proteins $(\mathrm{kDa})$ are as follows: 1,$81 ; 2,68 ; 3,48 ; 4,47 ; 5,28 ; 6$, $25 ; 7,20 ; 8,17 ; 9,16$.
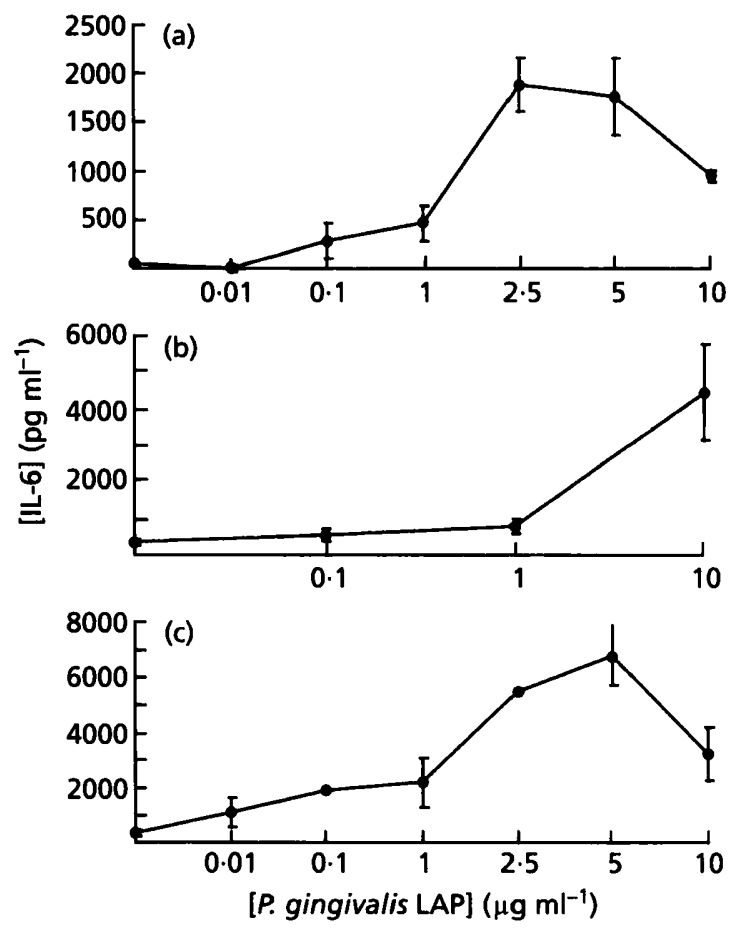

Fig. 2. IL-6 release by (a) HGFs, (b) whole blood and (c) human monocytes, stimulated with various concentrations of $P$. gingivalis LAPs. This is a typical result expressed as the means $\pm \mathrm{SD}(n=3)$.

Table 1. IL- 6 production by human monocytes induced with LPS from $E$. coli (E-LPS) and $P$. gingivalis (P-LPS) and LAP from $P$. gingivalis (P-LAP)

\begin{tabular}{|lcc|}
\hline $\begin{array}{l}\text { Cell } \\
\text { stimulant }\end{array}$ & LPS $\left(\mathrm{IU} \mathrm{m}^{-1}\right.$ ) & $\begin{array}{c}\text { IL-6 production } \\
\text { ( } \text { pg ml }^{-1} \text { ) }\end{array}$ \\
\hline E-LPS & 7 & $6000 \pm 98$ \\
P-LAP & 30 & $4010 \pm 62$ \\
P-LPS & 30 & $624 \pm 20$ \\
P-LPS & 300 & $642 \pm 5$ \\
P-LPS & 3000 & $2824 \pm 82$ \\
\hline
\end{tabular}

* Mean of triplicate experiments $\pm S D$.

treated LAPs; mean of triplicate experiments $\pm S D$ ). However, neither treatment completely abolished activity.

\section{Role of LPS contamination in the IL-6-inducing activity of the LAPs}

To assess the importance of the LPS contamination to the biological activity of the LAPs, the cytokine-inducing activity of both the P-LPS and the LAPs was compared with their LPS content as defined by their activity in the LAL assay. It was shown that 3000 IU P-LPS was required to stimulate a similar response to a LAP sample containing only 30 IU P-LPS (Table 1). 


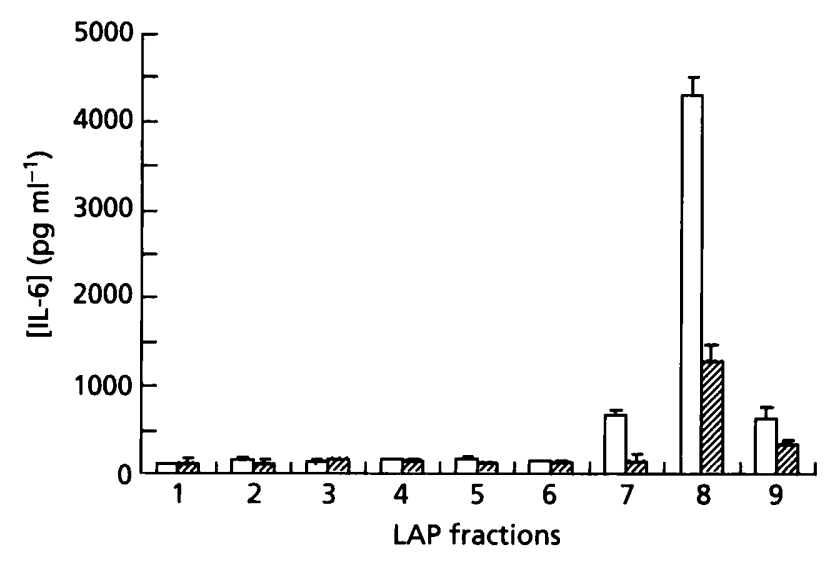

Fig. 3. IL-6 production by human monocytes stimulated with LAP fractions. LAPs were separated on SDS-PAGE and extracted from the polyacrylamide gel as described in Methods. Monocytes were treated with $10 \mu \mathrm{l}(\square)$ or $100 \mu \mathrm{l}(\square)$ of each fraction to identify the cytokine-stimulating components. A limited amount of stimulation was caused by fractions 7 and 9 but most of the activity is in fraction 8 , which corresponds to the $17 \mathrm{kDa}$ protein. Results are expressed as means of triplicate wells \pm SD.

\section{IL-6-stimulating activity of fractionated LAPs}

Electrophoresis of the undenatured LAPs in the presence of SDS resulted in a separation similar to that seen when the proteins were boiled in SDS sample buffer (Fig. 1). Unstained lanes in the polyacrylamide gel were compared with the Coomassie-blue-stained lanes in a parallel gel and areas corresponding to stained bands were cut out, eluted and dialysed before testing for activity on human PBMCs. As the protein content of each sample was too low to measure, 10 or $100 \mu \mathrm{l}$ of each fraction (from a total volume of $500 \mu \mathrm{l}$ ) was added to cells. The majority of the IL-6-stimulating activity coincided with the band corresponding to the $17 \mathrm{kDa}$ protein. The 16 and $20 \mathrm{kDa}$ proteins showed some limited activity and all other protein bands were inactive (Fig. 3).

\section{$\mathbf{N}$-terminal sequencing}

The active $17 \mathrm{kDa}$ protein was sequenced and had the following $\mathrm{N}$-terminal sequence, ADFTETFESSTHG$\operatorname{EAP}(\mathrm{A})$ EETTID. This sequence is highly homologous to a region of a putative haemagglutinating domain which is common to several gene products of $P$. gingivalis. These include the PrpRI (at A1139-D1161) and homologous arginine-specific proteases (AduseOpoku et al., 1995; Pavloff et al., 1995), Kgp (A1156D1178) (Pike et al., 1994), PrtP (A1157-D1179) (Barkocy-Gallagher et al., 1996), HagA (A687-D707, A1141-D1163, A1597-D1619 and A2053-A2075) (Naiming et al., 1996; Progulske-Fox et al., 1993) and the TonB-linked adhesin (A522-D544) (Aduse-Opoku et al., 1995). The $15 \mathrm{kDa}$ protein had the following, novel, sequence, AQGDNPDKDTDG(F)N.

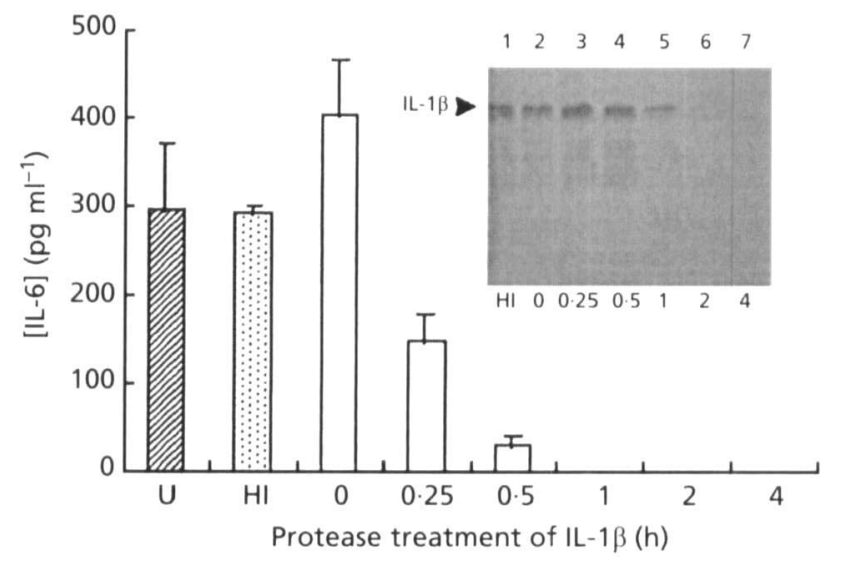

Fig. 4. Induction of IL-6 by IL- $1 \beta$ following RI protease treatment. The figure shows IL- 6 production from PBMCs treated with: $\mathrm{U}$, untreated $\mathrm{IL}-1 \beta ; \mathrm{HI}, \mathrm{IL}-1 \beta$ treated with heatinactivated RI protease; $0-4, \mathrm{IL}-1 \beta$ treated with RI protease for $0-4 \mathrm{~h}$ as described in the text. Inset shows a Western blot of IL$1 \beta$ treated as described above, detected with anti-human IL-1 $\beta$ polyclonal antibody.

\section{IL-1 $\beta$ degradation by purified RI protease}

Western blotting revealed that after $1 \mathrm{~h}$ incubation of IL- $1 \beta$ with RI protease there was a significant decrease of the intact cytokine in the sample. After $4 \mathrm{~h}$ incubation there was no detectable intact IL-1 $\beta$. In contrast, incubation of IL-1 $\beta$ with heat-inactivated RI protease for $4 \mathrm{~h}$ resulted in no degradation (Fig. 4). These data demonstrate that RI protease is able to degrade IL-1 $\beta$. The results from the bioassay (Fig. 4) showed a timedependent decrease in the IL-6-stimulating activity of the IL- $1 \beta$,-suggesting that IL- 6 has completely lost all biological activity within $1 \mathrm{~h}$.

\section{DISCUSSION}

$P$. gingivalis is now recognized as an important pathogen in certain forms of the chronic inflammatory periodontal diseases (Kurimatsu et al., 1995). Two of the major recognized virulence factors of this bacterium are its endotoxin/LPS (Watanabe et al., 1996) and its cellassociated and exported proteinases (Lantz et al., 1991; Kurimatsu et al., 1995). These proteinases are also major antigens in patients with periodontal disease (Cridland et al., 1994). In this study we have revealed an unexpected association between these apparently distinct putative virulence factors.

The proteins of the outer membranes of Gram-negative bacteria, known as LAPs or endotoxin-associated proteins, are an operationally defined group of proteins which co-isolate with LPS in endotoxin preparations and which can be separated from the LPS by extraction with hot phenol (Reddi et al., 1995b). The properties of the LAPs have been extensively reviewed by Hitchcock \& Morrison (1984). One important property is their stability to heat and proteases (Goodman \& Sultzer, 
1979a ; Bjornson et al., 1988; Johns et al., 1988). Enteric bacterial LAPs appear to be important virulence factors. For example, immunization of Salmonella-hypersusceptible mice with LAP-LPS complexes, but not with LPS alone, protects against the lethality of Salmonella typhimurium infections (Killion \& Morrison, 1986). The LAPs from several bacterial species have potent adjuvant activity (Mangan et al., 1993). Indeed, Hogan \& Vogel (1987) have suggested that the LAPs represent a 'second signal' for the activation of macrophages. Enteric LAPs are potent inducers of cytokine synthesis (Hogan \& Vogel, 1988) and can prevent monocytes from undergoing apoptosis (Mangan et al., 1993). Surprisingly, the identity of the proteins which constitute the LAPs of these various bacteria has not been defined and, to date, no protein sequence data on the LAPs have been reported.

Given these properties of the LAPs and their stability, it is possible that such proteins from oral Gram-negative bacteria could play a role in the pathology of the periodontal diseases (Reddi et al., 1995b). We have previously shown that the LAPs of Actinobacillus actinomycetemcomitans, $P$. gingivalis and Prevotella intermedia were able to induce HGFs or the human myeloid cell line, Mono-Mac-6, to produce pro-inflammatory cytokines (Reddi et al., 1995a). In addition, the LAPs of A. actinomycetemcomitans, $P$. gingivalis and Eikenella corrodens were able to stimulate the breakdown of cultured bone (Reddi et al., 1995a). Comparison of the LPS and LAPs of A. actinomycetemcomitans demonstrated that the latter were significantly more active inducers of cytokine synthesis than the former and when the LPS and LAPs of P. gingivalis and Prev. intermedia were tested they appeared to be equally potent and efficacious. While care was taken to ensure that the LAPs were not contaminated with residual LPS, these studies did not investigate the role of LPS in the biological activity of the LAPs.

In the present study we have attempted to define the mechanism of action of the LAPs isolated from the major periodontopathogen $P$. gingivalis and identify the active proteins. We have shown that preparations of LAPs from this bacterium stimulate HGFs, human PBMCs and whole human blood to synthesize the proinflammatory cytokine IL-6. Care was taken to remove any contaminating LPS in the LAPs preparation by use of a polymyxin B affinity column, and measurement of LPS contamination by the LAL assay showed that this treatment was effective in removing P-LPS. To determine if the capacity of the LAPs to induce cytokine synthesis was due to residual LPS, use was made of the knowledge that LPS-dependent effects can be blocked by the peptide antibiotic polymyxin B (Morrison \& Jacobs, 1976) or by a neutralizing antibody (MY4) to the LPS receptor CD14 (Viriyakosol \& Kirkland, 1996). We were unable to demonstrate inhibition of P-LPS with these agents (data not shown). This suggests that while polymyxin B can bind to P-LPS and remove it from the LAPs, this binding does not inhibit the biological activity of P-LPS. This confirms the findings of Hamada et al. (1988), who showed that polymxin B did not block the mitogenic activity of P-LPS. Exposure of the LAPs to heat or trypsin resulted in significant, but not total loss of activity. This clearly shows that LPS (which is stable to heat and proteases) is not responsible for the cytokineinducing activity of the LAPs. The failure to completely block the biological activity of the LAPs may be explained by the known stability of the proteins. In other experiments we have directly compared the relative activities of the LPS contamination in the LAP preparation with that of known concentrations of PLPS. This showed that 3000 IU P-LPS was required to produce the same cytokine-inducing activity as a LAP preparation contaminated with 30 IU LPS.

Thus based upon the measured LPS content of the LAPs, the inhibition of activity by heat and trypsin and the direct comparison of the activity of the LAPs with purified P-LPS, we conclude that the cytokine-inducing activity of the LAPs of $P$. gingivalis is due to these proteins and not to LPS contamination.

Analysis of the LAPs by SDS-PAGE revealed the presence of nine Coomassie-blue-stained protein bands of molecular masses ranging from 81 to $16 \mathrm{kDa}$. This raises the question of which of these proteins is responsible for the stimulation of IL- 6 synthesis. Unfortunately, because of the small amounts of proteins that can be obtained, and the problems with the solubility and 'stickiness' of the LAPs, it was impossible to isolate the individual proteins by conventional methods of protein purification. Other methodologies were investigated, and it was found that a modification of the conventional SDS-PAGE technique in which the LAPs were incubated in the SDS-PAGE sample buffer at room temperature, and not boiled, as is the normal practice, enabled these proteins to be separated (with the same pattern of bands as seen in conventional SDSPAGE) while retaining their biological activity. Using this technique, it was found that the cytokine-inducing activity of the LAPs was due predominantly to the $17 \mathrm{kDa}$ protein with the 16 and $20 \mathrm{kDa}$ proteins also showing limited activity. This finding is similar to that of Porat et al. (1992), who reported that the active component in the LAPs of E. coli was a $17 \mathrm{kDa}$ protein.

$\mathrm{N}$-terminal sequence analysis of the first 24 residues of the biologically active $17 \mathrm{kDa}$ protein demonstrated near identity with an internal region (A1139-D1161) of the RI protease $\beta$ chain and homologous haemagglutinating arginine-specific proteases (Aduse-Opoku et al., 1995), internal sequences of Lys-gingipain (Kgp; Pike et al., 1994), porphypain (PrtP; Barkocy-Gallagher et al., 1996), haemagglutinin A (Progulske-Fox et al., 1993; Naiming et al., 1996) and the TonB-linked adhesin of P. gingivalis (Aduse-Opoku et al., 1997). Furthermore, peptides in the size range $14-16 \mathrm{kDa}$ with this same $\mathrm{N}$-terminal sequence, thought to be derived via proteolytic processing of the respective precursors, have been identified in preparations of RI (Aduse-Opoku et al., 1995) and PrtP (Barkocy-Gallagher et al., 1996) purified from $P$. gingivalis. 
Recent studies have shown that supernatants and biofilms of $P$. gingivalis can hydrolyse and inactivate a number of pro- and anti-inflammatory cytokines including IL-6 (Fletcher et al., 1997, 1998). Another study has shown that $P$. gingivalis arginine-specific proteases and Lys-gingipain are able to inactivate the proinflammatory cytokine TNF- $\alpha$ (Calkins et al., 1998). In this study we have examined the direct action of the purified RI protease on IL- $1 \beta$ and have discovered that it degrades this cytokine and, in doing so, negates IL-1 bioactivity.

In conclusion, we have isolated the operationally defined fraction of proteins associated with the cell wall of $P$. gingivalis and termed LAPs, and have found that the active cytokine-inducing component of this mixed population of outer-membrane proteins is related, at the sequence level, to the adhesin domain common to products of the RI family of $P$. gingivalis. The critical determinants of the adhesin domain have yet to be fully characterized. However, it is reasonable to suggest the possibility that the IL-6-stimulating component found in these $P$. gingivalis LAPs contains determinants which can mediate binding to host cells and, in doing so, can trigger the production of IL-6. This production may be balanced by the capacity of the RI protease to proteolyse and inhibit the activity of cytokines. The exact balance of these two opposing effects is not clear but reveals the potential complexity of cytokine network interactions in the periodontal diseases.

\section{ACKNOWLEDGEMENTS}

The authors would like to thank Dr M. Ranjaran for donating the purified protease. The authors are grateful to the MRC for financial support for Dr Peter Tabona.

\section{REFERENCES}

Aduse-Opoku, J., Muir, J., Slaney, J. M., Rangarajan, M. \& Curtis, M. A. (1995). Characterization, genetic analysis, and expression of a protease antigen (PrpRI) of Porphyromonas gingivalis W50. Infect Immun 63, $4744-4754$.

Aduse-Opoku, J., Slaney, J. M., Rangarajan, M., Muir, J., Young, K. A. \& Curtis, M. A. (1997). The Tla of Porphyromonas gingivalis W50: a homologue of the arginine-specific protease precursor (PrpRI) which shares sequence similarity to TonB linked receptors. J Bacteriol 179, 4778-4788.

Barkocy-Gallagher, G. A., Han, N., Patti, J. M., Whitlock, J., Progulske-Fox, A. \& Lantz, M. S. (1996). Analysis of the prtP gene encoding porphypain, a cysteine proteinase of Porphyromonas gingivalis. J Bacteriol 178, 2734-2741.

Bjornson, B. H., Agura, E., Harvey, J., Johns, M., Andrews, R. G. \& McCabe, W. R. (1988). Endotoxin-associated protein: a potent stimulus for human granulopoietic activity which may be accessory cell independent. Infect Immun 56, 1602-1607.

Calkins, C. C., Platt, K., Potempa, J. \& Travis, J. (1998). Inactivation of tumor necrosis factor-alpha by proteinases (gingipains) from the periodontal pathogen, Porphyromonas gingivalis. Implications of immune system evasion. J Biol Chem 273, 6611-6614.

Cridland, J. C., Booth, V., Ashley, F. P., Curtis, M. A., Wilson, R. F. \& Shepherd, P. (1994). Preliminary characterisation of antigens recognised by monoclonal antibodies raised to Porphyromonas gingivalis and by sera from patients with periodontitis. $J$ Periodontal Res 29, 339-347.

Cunningham, M. D., Seachford, C., Ratcliffe, K., Bainbridge, B., Aruffo, A. \& Darveau, R. P. (1996). Helicobacter pylori and Porphyromonas gingivalis lipopolysaccharides are poorly transferred to recombinant soluble CD14. Infect Immun 64, 3601-3608.

Curtis, M. A., Aduse-Opoku, J., Slaney, J. M., Rangarajan, M., Booth, V., Cridland, J. \& Shepherd, P. (1996). Characterization of an adherence and antigenic determinant of the ArgI protease of Porphyromonas gingivalis which is present on multiple gene products. Infect Immun 64, 2532-2539.

Darveau, R. P. \& Hancock, R. E. W. (1983). Procedure for isolation of bacterial lipopolysaccharides from both smooth and rough Pseudomonas aeruginosa and Salmonella typhimurium strains. $J$ Bacteriol 155, 831-838.

Emancipator, K., Csako, G. \& Elin, R. J. (1996). In vitro inactivation of bacterial endotoxin by human lipoproteins and apoproteins. Infect Immun 60, 596-601.

European Pharmacopoeia (1997). Third edition. 2.6.14. Bacterial Endotoxins, pp. 29-37. Strasbourg: European Department for the Quality of Medicines.

Fletcher, J., Reddi, K., Poole, S., Nair, S., Henderson, B., Tabona, P. \& Wilson, M. (1997). Interactions between periodontopathogenic bacteria and cytokines. J Periodontal Res 32, 200-205.

Fletcher, J., Nair, S., Poole, S., Henderson, B. \& Wilson, M. (1998). Cytokine degradation by biofilms of Porphyromonas gingivalis. Curr Microbiol 36, 216-219.

Goodman, G. W. \& Sultzer, B. M. (1979a). Characterization of the chemical and physical properties of a novel B-lymphocyte activator, endotoxin protein. Infect Immun 24, 685-696.

Goodman, G. W. \& Sultzer, B. M. (1979b). Further studies on the activation of lymphocytes by endotoxin protein. J Immunol 122, 1329-1334.

Hamada, S., Toga, T., Nishihara, T., Fujiwara, T. \& Okahashi, N. (1988). Characterization and immunobiological activities of lipopolysaccharides from periodontal bacteria. Adv Dent Res 2, 284-291.

Hitchcock, P. J. \& Morrison, D. C. (1984). The protein component of bacterial endotoxins. In Handbook of Endotoxin, vol. 1, Chemistry of Endotoxin, pp. 339-374. Edited by E. T. Rietschel. Amsterdam: Elsevier.

Hogan, M. M. \& Vogel, S. N. (1987). Lipid A-associated proteins provide an alternative "second signal" in the activation of recombinant interferon-gamma-primed $\mathrm{C} 3 \mathrm{H} / \mathrm{HeJ}$ macrophages to a fully tumoricidal state. J Immunol 139, 3697-3702.

Hogan, M. M. \& Vogel, S. N. (1988). Production of tumor necrosis factor by rIFN-gamma-primed $\mathrm{C} 3 \mathrm{H} / \mathrm{HeJ}$ (Lpsd) macrophages requires the presence of lipid A-associated proteins. J Immunol 141, 4196-4202.

Johns, M. A., Sipe, J. D., Melton, L. B., Strom, T. B. \& McCabe, W. R. (1988). Endotoxin-associated protein : interleukin-1-like activity on serum amyloid $A$ synthesis and $\mathrm{T}$-lymphocyte activation. Infect Immun 56, 1593-1601.

Killion, J. W. \& Morrison, D. C. (1986). Protection of C3H/HeJ mice from lethal Salmonella typhimurium LT2 infection by immunization with lipopolysaccharide-lipid A-associated protein complexes. Infect Immun 54, 1-8.

Kurimatsu, H. K., Yoneda, M. \& Madden, T. (1995). Proteases and collagenases of Porphyromonas gingivalis. Adv Dent Res 9, $37-40$.

Laemmli, U. K. (1970). Cleavage of structural proteins during the assembly of the head of bacteriophage T4. Nature 227, 680-685. 
Lantz, M. S., Allen, R. D., Duck, L. W., Switalski, L. M. \& Hook, M. (1991). Porphyromonas gingivalis surface components bind and degrade connective tissue proteins. J Periodontal Res 26, 283-285.

Mangan, D. F., Wahl, S. M., Sultzer, B. M. \& Mergenhagen, S. E. (1993). Stimulation of human monocytes by endotoxin-associated protein: inhibition of programmed cell death (apoptosis) and potential significance in adjuvancy. Infect Immun 60, 1648-1686.

Matsudaira, P. (1987). Sequence from picomole quantities of proteins electroblotted onto polyvinylidene difluoride membranes. J Biol Chem 262, 10035-10038.

Morrison, D. C. \& Jacobs, D. M. (1976). Binding of polymyxin B to the lipid-A region of bacterial LPS. Immunochemistry 13, 815-818.

Morrison, D. C. \& Leive, L. (1975). Fractions of lipopolysaccharides from $E$. coli $0111: \mathrm{B} 4$ prepared by two extraction procedures. J Biol Chem 250, 2911-2919.

Naiming, H. A., Whitlock, J. \& Progulske-Fox, A. (1996). The hemagglutinin gene $\mathrm{A}$ ( hagA) of Porphyromonas gingivalis 381 contains four large contiguous direct repeats. Infect Immun 64, $4000-4007$.

Pavloff, N., Potempa, J., Pike, R. N., Prochazka, V., Kiefer, M. C., Travis, J. \& Barr, P. J. (1995). Molecular cloning and structural characterization of the Arg-gingipain proteinase of Porphyromonas gingivalis. Biosynthesis as a proteinase-adhesin polyprotein. J Biol Chem 270, 1007-1010.

Phillips, M., Castagna, R., Sultzer, B. M. \& Eisenstein, T. K. (1989). Immunogenic endotoxin associated protein from a rough strain of Salmonella. FEMS Microbiol Immunol 1, 485-490.

Pike, R., McGraw, W., Potempa, J. \& Travis, J. (1994). Lysine- and arginine-specific proteinases from Porphyromonas gingivalis. Isolation, characterization and evidence for the existence of complexes with hemagglutinins. J Biol Chem 269, 406-411.

Porat, R., Yanoov, M., Johns, M. A., Shibolet, S. \& Michalevicz, R. (1992). Effects of endotoxin-associated protein on hematopoiesis. Infect Immun 60, 1756-1760.

Progulske-Fox, A., Rao, V., Han, N., Lepine, G., Witlock, J. \& Lantz, M. (1993). Molecular characterization of hemagglutinin genes of periodontopathic bacteria. J Periodontal Res 28, 473-474.

Reddi, K., Meghji, S., Wilson, M. \& Henderson, B. (1995a). Comparison of the osteolytic activity of surface-associated proteins of bacteria implicated in periodontal disease. Oral Dis 1, 26-31.

Reddi, K., Poole, S., Nair, S., Meghji, S., Henderson, B. \& Wilson, M. (1995b). Lipid A-associated proteins from periodontopathogenic bacteria induce interleukin- 6 production by human gingival fibroblasts and monocytes. FEMS Immunol Med Microbiol 11, 137-144.

Reife, R. A., Shapiro, R. A., Bamber, B. A., Berry, K. K., Mick, G. E. \& Darveau, R. P. (1995). Porphyromonas gingivalis lipopolysaccharide is poorly recognized by molecular components of innate host defence in a mouse model of early inflammation. Infect Immun 63, 4686-4694.

Sultzer, B. M. (1968). Genetic control in leukocyte responses to endotoxin. Nature 219, 1253-1254.

Sultzer, B. M. (1969). Genetic factors in leukocyte responses to endotoxin: further studies in mice. J Immunol 103, 32-38.

Sultzer, B. M. \& Goodman, G. W. (1976). Endotoxin protein : a Bcell mitogen and polyclonal activator of $\mathrm{C} 3 \mathrm{H} / \mathrm{HeJ}$ lymphocytes. $J$ Exp Med 144, 821-827.

Sultzer, B. M., Craig, J. P. \& Castagna, R. (1985). The adjuvant effect of pertussis endotoxin protein in modulating the immune response to cholera toxoid in mice. Dev Biol Stand 61, 225-232.

Taktak, Y. S., Selkirk, S., Bristow, A. F., Carpenter, A., Ball, C., Rafferty, B. \& Poole, S. (1991). Assay of pyrogens by interleukin6 release from monocytic cell lines. J Pharm Pharmacol 43, 578-582.

Towbin, H., Staehelin, T. \& Gordon, J. (1979). Electrophoretic transfer of protein from polyacrylamide gels to nitrocellulose sheets : procedure and some applications. Proc Natl Acad Sci USA 76, 4350-4354.

Viriyakosol, S. \& Kirkland, T. N. (1996). The N-terminal half of membrane CD14 is a functional cellular lipopolysaccharide receptor. Infect Immun 64, 653-656.

Watanabe, A., Takeshita, A., Kitano, S. \& Hanazawa, S. (1996). CD14 mediated signal pathway of Porphyromonas gingivalis lipopolysaccharide in HGFs. Infect Immun 11, 4484-4494.

Westphal, O. \& Jann, K. (1965). Bacterial lipopolysaccharide. Extraction with phenol-water and further applications of the procedure. Methods Carbobydr Chem 5, 83-91.

Wilson, M., Meghji, S., Barber, P. \& Henderson, B. (1993). Biological activities of surface-associated material from Porphyromonas gingivalis. FEMS Immunol Med Microbiol 6, 147-155.

Wober, W. \& Alaupovic, P. (1971). Studies on the protein moiety of endotoxin from gram-negative bacteria. Characterization of the protein moiety isolated by phenol treatment of endotoxin from Serratia marcescens 08 and Escherichia coli 0 141:K85(B) Eur J Biochem 19, 340-356.

Wurfel, M. M., Kunitake, S. T., Lichenstein, H., Kane, J.P. \& Wright, S. D. (1994). Lipopolysaccharide-binding protein is carried on lipoproteins and acts as a co-factor in the neutralization of LPS. J Exp Med 180, 1025-1035.

Wurfel, M. M., Hailman, E. \& Wright, S. D. (1995). Soluble CD14 acts as a shuttle in the neutralization of LPS by LPS binding protein and reconstituted lipoprotein. J Exp Med 181, 1743-1745.

Ziegler-Heitbrock, H. W., Frankenberger, H. \& Wedel, A. (1995). Tolerance to lipopolysaccharide in human blood monocytes. Immunobiology 193, 217-223.

Received 25 March 1998; revised 30 June 1998; accepted 13 July 1998. 